\title{
PENGEMBANGAN PROGRAM CAI DALAM PEMBELAJARAN PAI MATERI HAJI DAN UMRAH UNTUK SISWA MADRASAH TSANAWIYAH
}

\author{
Moch. Fuad, Anik Ghufron \\ Program Studi Teknologi Pembelajaran PPs UNY, Universitas Negeri Yogyakarta \\ mochfuadsy@gmail.com, anikgh@telkom.net
}

\begin{abstract}
Abstrak
Penelitian ini bertujuan untuk: (1) menghasilkan produk media pembelajaran Fikih materi Haji dan Umrah dalam program CAI untuk siswa MTs., (2) membuktikan kelayakan media pembelajaran Fikih dalam bentuk CD sebagai media pembelajaran dan sumber belajar, (3) membuktikan kontribusi media pembelajaran Fikih dalam proses pembelajaran di kelas. Metode yang digunakan adalah penelitian pengembangan (Research and Development) melalui: analisis kebutuhan, mendesain pembelajaran, pengembangan multimedia, evaluasi, dan uji coba. Evaluasi dan validasi produk media dilakukan oleh seorang ahli media dan 5 orang ahli materi, sedang uji coba dilaksanakan di MTs. Negeri Yogyakarta 1 melalui uji coba one on one ( 3 orang siswa), uji coba sampel kecil (10 orang siswa), dan uji coba program (36 orang siswa). Penelitian pengembangan (Research and Development) ini menghasilkan media CD pembelajaran Fikih materi Haji dan Umrah untuk siswa MTs; media CD pembelajaran dinyatakan layak berdasarkan validasi ahli media dengan skor 3,17 (baik); validasi ahli materi dengan skor 3,52 (sangat baik); sedang hasil uji coba kepada siswa dengan skor rata-rata 3,41 (baik). Media pembelajaran ini memberi sumbangan dalam proses pembelajaran di kelas yaitu siswa merasa mudah mempelajari materi; materi pembelajaran menjadi menarik; memberi umpan balik kepada siswa dan guru, dan memotivasi siswa untuk selalu belajar dengan skor rata-rata 3,37 (84,25\%).
\end{abstract}

Kata kunci: CAI (computer assisted instruction), pembelajaran PAI

\begin{abstract}
This research aims to: (1) produce instructional media of Fikih on the topic of Hajj and Umrah through CAI programs for MTs students, (2) prove the feasibility of developed instructional media of Fikih in the form of a CD viable as a medium of teaching and learning resources, and (3) prove the contribution of the intructional media of Fikih in the classroom teaching and learning process. The method used is Research and Development through: needs analysis, instructional design, multimedia development, evaluation, and testing. Evaluation and validation of media products by the media expert and the 5 people subject matter experts, the test is being conducted in State MTs Yogyakarta 1 through one on one test (3 students), test a small sample (10 students), and the test program (36 students). Research and Development produces CD instructional media of Figh on the topic of Hajj and Umrah for MTs students; this instructional media is considered feasible by media experts with a score of 3.17 and by material experts with a score of 3.52 (very good), being the test results to students with an average score of 3.41 (good). This instructional media gives benefit to the classroom teaching process, in that the students learn the material more easily and the material becomes more interesting. The media could give feedback to students and the teacher. In addition, the media could motivate students in learning, which is showed by the average score of 3.37 (84.25\%).
\end{abstract}

Keywords: CAI (computer assisted instruction), the PAI learning. 


\section{Pendahuluan}

Pelaksanaan pendidikan agama dalam konteks pendidikan bangsa merupakan masalah yang fundamental dan kompleks. Pendidikan agama menekankan ajaran moral, dan moralitas itu menjadi sumber solidaritas dalam pergaulan hidup. Dalam UUSPN No. 20 Tahun 2003 ditegaskan, bahwa tujuan pendidikan agama pada dasarnya adalah mengembangkan watak manusia sesuai dengan tuntutan iman. Secara operasional pendidikan agama bertujuan mengembangkan sikap dan pandangan hidup yang didasarkan pandangan agama, dan dapat dikembangkan dalam kehidupan di masyarakat. Dengan demikian pelaksanaan pendidikan agama mempunyai nilai tambah dalam mencerdaskan kehidupan bangsa dan melandasi perkembangan ilmu pengetahuan dan teknologi.

Pada kondisi realitas, Pendidikan Agama Islam (PAI) di sekolah maupun di madrasah mengalami "kesenjangan" antara dasar pemikiran, teori dan praktik pelaksanaan di lapangan, yaitu adanya problem internal dan eksternal. Problem internal menyangkut program, pemahaman, perencanaan, pelaksanaan, penerapan, dan evaluasi sistem PAI masih dianggap belum mencapai tujuan. Strategi dan metode pembelajaran yang digunakan guru agama masih dengan cara "lama". Sedangkan problem eksternal PAI senantiasa berhadapan dengan kemajuan ilmu pengetahuan dan teknologi, globalisasi informasi, perubahan politik, ekonomi, sosial dan budaya bangsa. Dua faktor ini yang dianggap sebagai kendala pembelajaran PAI di sekolah dan madrasah.

Pada aspek pedagogik, pemanfaatan media dan teknologi informasi dalam pendidikan merupakan salah satu bagian yang tidak dapat dihindari dan diharapkan akan dapat menjadi alternatif pemecahan masalah dalam pembelajaran PAI. Menurut Sadiman, dkk. fungsi media dalam pembelajaran adalah untuk membantu siswa dan guru mengatasi kesulitan dalam proses pembelajaran, memberikan peng- alaman lebih nyata yaitu yang abstrak dapat menjadi kongkret, jalannya proses pembelajaran tidak membosankan, semua indera siswa dapat diaktifkan, lebih menarik perhatian dan minat siswa dalam belajar, dan dapat membangkitkan dunia teori dalam realita (Sadiman, dkk., 2008, pp.17-18). Oleh karena itu, diperlukan model pembelajaran berbasis teknologi informasi yang dapat dimanfaatkan oleh para guru di sekolah dan madrasah. Salah satu produk teknologi yang dinilai tepat digunakan untuk meningkatkan keefektifan dalam proses pembelajaran tersebut adalah program pembelajaran berbantuan komputer atau CAI (Computer Assisted Instruction). Dalam program CAI (Computer Assisted Instruction), perangkat komputer digunakan sebagai sarana untuk mengembangkan dan mengoperasikan media pembelajaran yang dapat membantu peserta didik dan guru dalam memahami suatu konsep, merumuskan dan mempraktikkan (Orey, et.all, 2006, pp.144-145).

Menurut Michael J. Hannafin \& Kyle L. Peck, dalam The Design, Development and Evaluation of Instructional Software, bahwa tahapan pembelajaran melalui CAI (Computer Assisted Instruction) meliputi tahap penilaian kebutuhan, tahap perancangan serta tahap pengembangan dan implementasi (Hannafin \& Peck, 1988, p.80). Oleh karenanya berbagai macam pendekatan pembelajaran dapat dikemas dalam program pembelajaran berbantuan komputer atau CAI (Computer Assisted Instruction), seperti: drill and practice, simulasi, problem solving, tutoial dan permainan. Pembelajaran berbantuan komputer dinilai tepat karena mempunyai beberapa kelebihan, yaitu: (l) dapat meningkatkan motivasi belajar siswa, (2) memberikan infomasi tentang kesalahan dan jumlah waktu belajar serta waktu untuk mengerjakan soal-soal kepada siswa, (3) mengatasi kelemahan pada pembelajaran kelompok, (4) melatih siswa untuk terampil memilih bagian-bagian isi pelajaran yang dikehendaki, (5) bermanfaat bagi siswa yang biasanya kurang dapat mengikuti metode pembelajaran konvensional, (6) mengu- 
rangi rasa malu dalam proses pembelajaran, (7) mendukung pembelajaran individual, (8) memungkinkan siswa untuk lebih mengenal dan terbiasa dengan komputer, (9) menciptakan pembelajaran yang enjoy, dan (10) komputer merupakan media penyampaian pembelajaran yang efektif (Ismaniati, 2001, pp.26-27).

Berdasarkan kelebihan pembelajaran berbantuan komputer di atas maka sudah saatnya pembelajaran PAI di madrasah memanfaatkan media ini dan mulai mengubah model pembelajaran yang konvensional. Oleh karena itu guru PAI di madrasah dituntut mampu menerapkan model dengan pendekatan saintifik (scientific approach) dan pendekatan pembelajaran yang berpusat kepada siswa (student center) serta menekankan pada penilaian autentik (autentical evaluation), menerapkan model pembelajaran penemuan (discovery learning), pembelajaran berbasis proyek (project based learning) serta pembelajaran berbasis pemecahan masalah (problem based learning). Dalam konteks pendidikan secara umum disebutkan bahwa pelaksanaan pendidikan harus membangun ranah kognitif, afektif dan psikomotorik (Conny R. Semiawan, 1995, pp.28-29). Artinya dasar PAI dengan sifatnya yang normatif dan universal mengambil tempat pada bagian dasar keseluruhan kerangka pendidikan, maka di dalam pelaksanaannya dibutuhkan interaksi pendidikan dan strategi pembelajaran (Azumardi Azra, 1999, pp.20-25).

Kesenjangan yang terjadi di lapangan antara tujuan PAI dengan pelaksanaannya, baik yang bersifat keagamaan (ibadah maghdoh) maupun kemasyarakatan (ibadah ghoiru maghdoh) mengalami "ambivalensi pratik", artinya orang selalu bertanya apakah dengan PAI mampu mengantarkan peserta didik untuk patuh beragama?, atau mampukah PAI menumbuhkan dan mewujudkan ke"salehan sosial" kepada peserta didik?, "kesalehan sosial" yang dimaksud adalah kesadaran seseorang dalam menumbuhkan dan mewujudkan ajaran agama dalam kehidupan kemasyarakatan, di samping kepatuhannya melaksanakan ajaran agama secara personal (ibadah maghdoh). Dalam paparan Kuntowijoyo (2005, pp.85-96) dalam bukunya berjudul, Islam Sebagai Ilmu: Epistemologi, Metodologi dan Etika, bahwa persoalan keagamaan Islam dan PAI sangatlah memerlukan pemikiran yang mendalam dan utuh dalam menjelaskan ajaran agama pada kehidupan individu dan masyarakat. Aksentuasi dan aplikasi iman dan hukum fikih harus dapat menjelaskan dan memayungi persoalan kehidupan sosial kemasyarakatan, maka diperlukan pembebasan yang bernuansa profetik (bahwa sumber ilmu pengetahuan itu tidak hanya dari rasio dan empiri, tetapi juga dari wahyu) dan berbasis civil society (kesejahteraan umum). Dalam menghadapi masalah ini, PAI tidak hanya dituntut sanggup menanamkan "doktrin" agama, namun juga mampu menanamkan akhlak dan budi pekerti serta pelaksanaan hukum fikih (ibadah). Berdasarkan kenyataan tersebut niscaya pelaksanaan PAI sangat membutuhkan pengembangan, perbaikan, penyesuaian, dan kearifan. Dalam proses pelaksanaannya; meliputi: pengembangan kurikulum, pendekatan dan strategi pembelajaran, serta penggunaan media pembelajaran sehingga peserta didik dan guru dapat melakukan proses pembelajaran dengan aktif, kreatif, efeftif dan menyenangkan.

Kementerian Agama RI melalui Direktorat Jenderal Kelembagaan Agama Islam pada Tahun 2004 telah melakukan arah baru pengembangan Pendidikan Agama Islam (PAI) pada sekolah umum dan madrasah (Departemen Agama RI, 2004, pp.26-38). Arah baru pengembangan tersebut meliputi: pengembangan model pembelajaran, pengembangan media pembelajaran berbantuan komputer, penyediaan bahanbahan acuan operasional pembelajaran, meningkatkan kualitas guru PAI melalui penataran pengembangan strategi dan metode pembelajaran PAI yang efektif termasuk memakai alat bantu komputer, memberdayakan peranan masyarakat dalam pembelajaran PAI, dan model Dakwah Sistim Langsung (DSL). Melihat perubahan dan paradigma tersebut sesungguhnya 
dalam pandangan pendidikan Islam (AtTarbiyyah al-Islamiyah), menurut Ali AlJumlati dalam Dirrasah muqaranah fi alTarbiyah, al-Islamiyah sebagaimana yang disampaikan Imam Al-Ghozali, bahwa dalam poses pembelajaran agar mencapai tujuan harus menggunakan pengaruh dan cara yang tepat arah dan sangat dianjurkan (sunah al-muakad) (Al-Jumlati,1973, p.22). Pandangan Imam Al-Ghozali tersebut menunjukkan pentingnya guru mengembangkan strategi dan media dalam proses pembelajaran. Dalam konteks pembahasan ini bahwa sangat dianjurkan untuk melaksanakan pembelajaran PAI dengan memakai alat bantu komputer atau CAI (Computer Assisted Instruction).

Berdasarkan pemikiran di atas dan studi pendahuluan yang dilakukan peneliti di beberapa MTs Negeri dan swasta di kotaYogyakarta, bahwa masih sedikit guru PAI di Madrasah Tsanawiyah yang menggunakan media pembelajaran berbasis komputer, itupun dengan program PowerPoint dan "video-jadi" seadanya. Padahal ada beberapa materi PAI yang sangat memerlukan media audio visual dalam proses pembelajarannya, seperti materi fikih yaitu sholat, zakat, haji, dan pelajaran membaca Al-Qur'an. Di samping itu ada anggapan sebagian besar siswa bahwa mata pelajaran PAI dirasakan sebagai materi pelajaran yang kurang menarik. Pada hal menurut pendapat para guru di MTs. mata pelajaran PAI terutama materi Haji dan Umrah penting untuk siswa karena materi ini masuk "ibadah Maghdoh" dan perlu dipraktekkan oleh siswa madrasah, sementara siswa kurang berminat atau kurang tertarik. Hal tersebut disebabkan karena beberapa faktor antara lain: (1) pembelajaran masih didominasi oleh guru dengan metode ceramah, (2) guru masih banyak berakting didepan kelas sehingga siswa akan bersifat pasif dan komunikasi hanya bersifat searah, (3) adanya kesalahan persepsi bahwa guru dianggap paling segalanya, sehingga siswa kurang mendapat kesempatan untuk berkreasi yang akhirnya siswa hanya belajar dari apa kata guru, bukan dari pengalaman yang di gali oleh siswa sendiri melalui media dan sumber belajar, (4) pemberdayaan sumber belajar terutama penggunaan media berbasis komputer atau CAI masih terbatas, sehingga metode ceramah masih mendominasi, (5) pembelajaran belum mengintegrasikan antara pengetahuan (knowledge), kecakapan (life skill) dan nilai moral, yang seperti ini niscaya memerlukan pengembangan media pembelajaran.

Dasar akademik dan praktik di lapangan tersebut menjadi referensi untuk melakukan penelitian tentang "Pengembangan Program CAI dalam pembelajaran PAI materi Haji dan Umrah untuk siswa MTs. Pertimbangan yang diambil adalah: (1) untuk memperbaiki cara guru PAI di MTs. melaksanakan proses pembelajaran, (2) mempermudah dan memotivasi siswa MTs. cinta dan aktif belajar agama secara mandiri, dan pembelajaran PAI menjadi lebih efektif, dan (3) meningkatkan pencapaian ranah kognitif, afektif dan psikomotorik siswa.

Berdasarkan latar belakang di atas, maka rumusan masalah penelitian ini adalah: (1) bagaimana mengembangan media pembelajaran PAI berbasis proyek melalui program CAI pada siswa MTs.? (2) apakah produk media pembelajaran PAI yang dikembangkan layak untuk diterapkan sebagai media pembelajaran? (3) bagaimana kontribusi media pembelajaran PAI bagi siswa MTs. dalam proses pembelajaran di kelas? Adapun tujuan penelitian ini adalah: (1) menghasilkan produk media pembelajaran melalui pengembangan program CAI dalam pembelajaran PAI materi Haji dan Umrah untuk siswa MTs., (2) membuktikan bahwa pengembangan media pembelajaran PAI dalam bentuk CD layak sebagai media pembelajaran dan sumber belajar, (3) membuktikan kontribusi media pembelajaran PAI bagi siswa MTs. dalam proses pembelajaran di kelas.

Penelitian dan Pengembangan (Research and Development) tentang pengembangan program CAI dalam pembelajaran PAI materi Haji dan Umrah untuk siswa MTs. dilakukan karena beberapa hal, yaitu: (1) untuk mencari alternatif pemecahan 
masalah dalam pembelajaran Fikih, sehingga siswa tetap memiliki semangat, motivasi dan mudah dalam belajar, (2) guru dapat mengajar dengan baik dan mudah meski muatan materi Fikih luas dengan waktu yang terbatas, (3) laboratorium komputer MTs. Negeri Yogyakarta 1 dapat dimanfaatkan secara maksimal untuk kegiatan pembelajaran, dan (4) guru dan siswa MTs. terbiasa menggunakan produk media yang dikembangkan dengan program CAI.

\section{Metode Penelitian}

Jenis Penelitian

Jenis penelitian ini adalah penelitian pengembangan atau Research and Development yaitu penelitian yang berorientasi pada produk. Produk yang dikembangkan dalam penelitian ini adalah "multimedia interaktif pembelajaran Fikih materi Haji dan Umrah untuk siswa MTs". Model pengembangan penelitian yang digunakan adalah adaptasi langkah-langkah penelitian pengembangan yang dikemukakan oleh Borg \& Gall (1983) dan Anik Ghufran (2007), yaitu: (1) melakukan penelitian pendahuluan dan pengumpulan informasi termasuk kajian pustaka, observasi kelas, dan penyiapan pokok-pokok permasalahan, (2) melakukan perencanaan termasuk menentukan ketrampilan, perumusan tujuan, penentuan urutan pembelajaran, dan uji coba skala terbatas, (3) mengembangkan bentuk produk awal termasuk penyiapan materi pembelajaran, bahan ajar, dan alat evaluasi, (4) melakukan uji coba lapangan, (5) melakukan revisi terhadap produk utama sesuai dengan saran-saran dari ahli media dan ahli materi, (6) melakukan uji coba kepada siswa. Langkah tersebut dapat diringkas menjadi empat langkah, yakni perencanaan, pengembangan, uji lapangan, dan diseminasi (Anik Ghufron, 2007, p.10). Lihat visualisasi pada gambar 1.

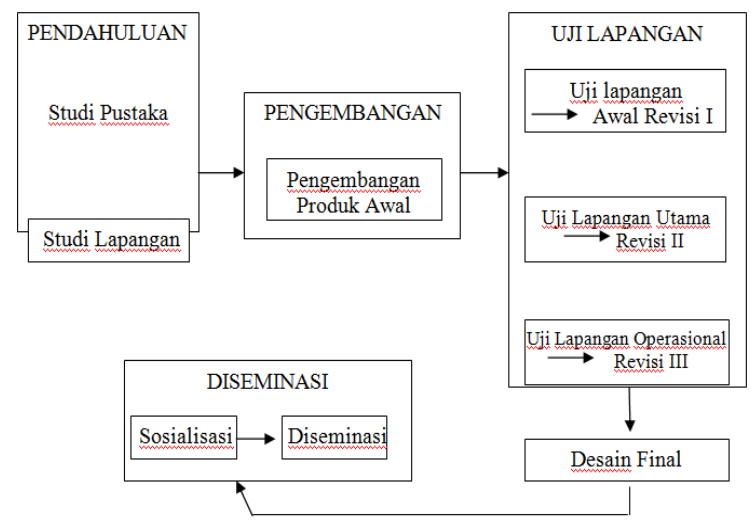

Gambar 1. Langkah-Langkah Penelitian dan Pengembangan (Adaptasi dari Borg \& Gall, 1983; Anik Ghufron, 2007)

Prosedur

Prosedur pengembangan yang digunakan dalam penelitian ini adalah model desain pembelajaran yang dikemukakan oleh Dick \& Carey (2001, p.1), sedang desain pengembangan multimedia yang digunakan adalah model pengembangan Luther (lihat Ariesto Hadi Sutopo, 2003, pp.32-48). Sedang untuk desain evaluasi produk diambil dari model evaluasi formatif Dick \& Carey (2001, pp.304-305) yang terdiri dari tiga tahap yaitu: one to one evaluation, small group evaluation, dan field evaluation (lihat gambar 2 dan 3 ).

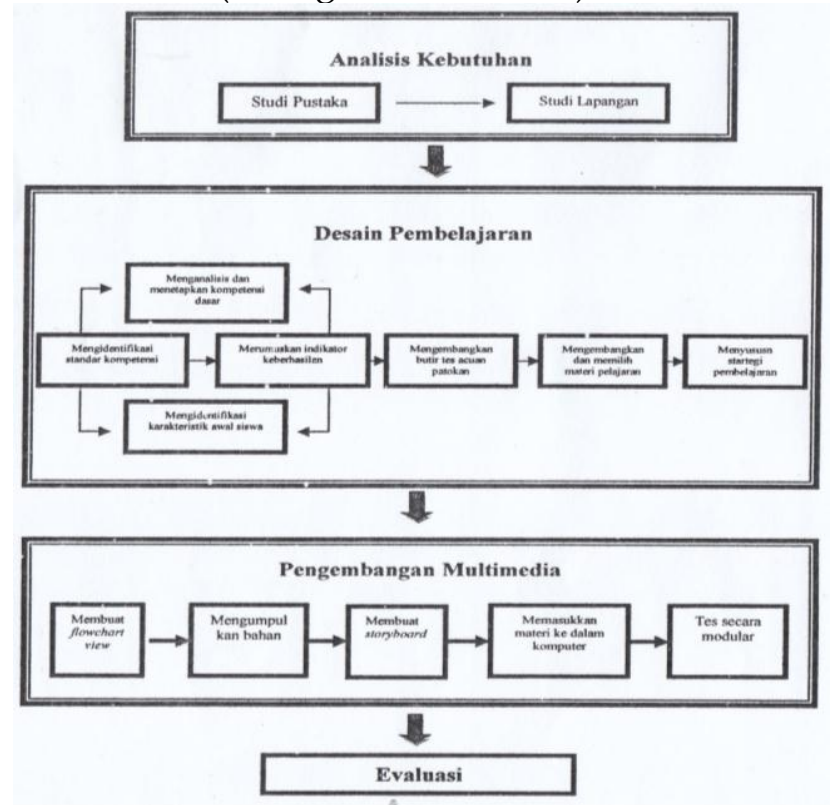

Gambar 2. Bagan prosedur pengembangan (Diadaptasi dari Borg \& Gall (1983), Dick \& Carey (2001),dan Luther dalam Ariesto Hadi Sutopo (2003, pp.32-48) 


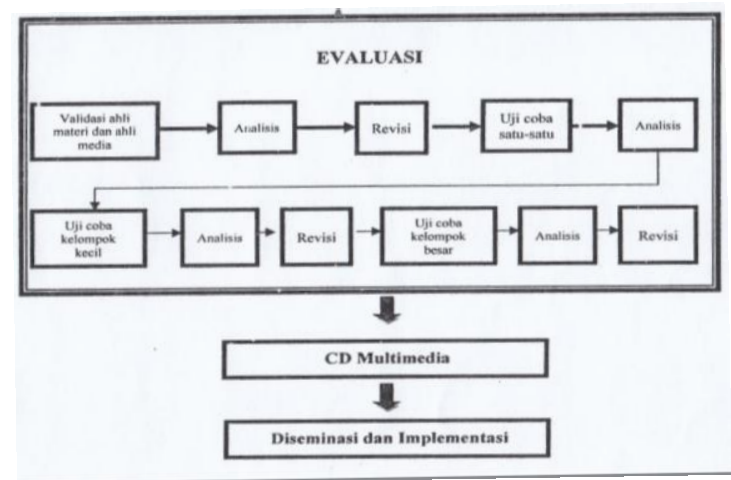

Gambar 3. Bagan prosedur pengembangan (Diadaptasi dari Borg \& Gall (1983), Dick \& Carey (2001), dan Luther dalam Ariesto Hadi Sutopo (2003, pp.32-48)

Data, Instrumen, dan Teknik Pengumpulan Data

Sebelum produk tersebut diujicobakan kepada siswa MTs. Negeri Yogyakarta 1 terlebih dahulu divalidasi oleh ahli media dan ahli materi. Setelah divalidasi, uji coba dilakukan pada siswa dengan tiga tahapan yaitu uji coba satu-satu sebanyak 3 orang, uji coba kelompok kecil sebanyak 10 orang, dan uji coba lapangan (kelompok besar) 36 orang. Instriumen yang digunakan untuk mengumpulkan data pada penelitian ini berupa obeservasi, wawancara, dan angket. Data yang terkumpul yaitu data kuantitatif yang diperoleh dari angket yang diberikan kepada ahli media, ahli materi, dan siswa. Sedang data kualitatif yang diperoleh dari hasil observasi dan wawancara dari ahli media, ahli materi, dan siswa dihimpun dan disimpulkan untuk memperbaiki produk multimedia pembelajaran ini.

Teknik Analisis Data

Data yang diperoleh dari observasi dan wawancara kepada guru dan siswa MTs. Negeri Yogyakarta 1, ahli media, dan ahli materi dianalisis secara deskriptif kualitatif. Sedang data hasil dari angket dikuantifikasikan ke dalam angka sehingga menjadi data kuantitatif. Analisis data kuantitatif dalam penelitian ini menggunakan statistik deskriptif, yang berupa pernyataan kurang, cukup, baik, dan sangat baik yang diubah menjadi data kuantitatif dengan skala 4 yaitu penskoran 1 sampai 4 . Proses dalam analisis data antara lain: (a) mengumpulkan data mentah, (b) pemberian skor, (c) skor yang diperoleh kemudian dikonversikan menjadi nilai dengan skala 4 dengan menggunakan acuan konversi pada Tabel 1.

Tabel 1. skala persentase menurut Arikunto (1996, p.244)

\begin{tabular}{ccc}
\hline $\begin{array}{c}\text { Persentase } \\
\text { Pencapaian }\end{array}$ & Skala Nilai & Interpretasi \\
\hline $90-100 \%$ & $3,6-4$ & Sangat Baik \\
$75-85 \%$ & $3-3,5$ & Baik \\
$50-65 \%$ & $2-2,9$ & Cukup \\
$0-49 \%$ & $1-1,9$ & Kurang \\
\hline
\end{tabular}

Berdasarkan konversi skor ke nilai maka nantinya didapat skor indek hasil analisis nilai produk multimedia pembelajaran yang dikembangkan.

\section{Hasil Penelitian dan Pengembangan}

\section{Analisis Kebutuhan}

Tahap analisis kebutuhan dilakukan untuk mendapatkan berbagai informasi tentang mata pelajaran apa yang sangat membutuhkan sebuah media pembelajaran pada Madrasah Tsanawiyah Negeri Yogyakarta 1. Langkah-langkah yang dilakukan dalam analisis kebutuhan ini adalah studi pustaka dan studi lapangan. Kegiatan studi pustaka diperoleh data tentang mata pelajaran Fikih yang sangat membutuhkan media pembelajaran khususnya untuk materi haji dan Umrah. Studi pustaka ini dilakukan dengan mempelajari kurikulum (SAP) mata pelajaran Fikih untuk melihat muatan materi, alokasi waktu yang tersedia, standar kompetensi, dan kompetensi dasar Fikih di MTs. Berdasarkan studi pustaka diperoleh kesimpulan bahwa mata pelajaran Fikih sangat membutuhkan sebuah media pembelajaran untuk membantu dan memudahkan guru dan siswa dalam pembelajaran.

Studi lapangan dilakukan untuk melihat keadaan di madrasah secara langsung yaitu dengan cara observasi dan wawancara. Data yang diperoleh dari hasil 
observasi adalah bahwa guru dalam pembelajaran Fikih jarang (kurang) menggunakan media pembelajaran, selalu menggunakan metode ceramah dalam mengajar, siswa pasif dan kurang berminat dalam mengikuti pelajaran. Hal ini tampak ketika proses pembelajaran berlangsung di kelas dan pernyataan siswa ketika dilakukan wawancara.

Pengembangan Produk

Langkah pertama dalam mengembangkan produk pengembangan program CAI (Computer Assisted Instruction) dalam pembelajaran PAI materi Haji dan Umrah untuk siswa MTs. adalah membuat flowchart. Flowchart adalah diagram alur yang akan menjadi dasar dalam membuat langkah-langkah dan hubungan (link) antar materi dalam media pada masing-masing slide.

Setelah flowchart sudah jadi, tahap berikutnya adalah mengumpulkan bahanbahan pendukung yang terdiri dari video, gambar-gambar dan animasi-animasi yang akan digunakan dalam pembuatan media pembelajaran. Bahan-bahan yang dikumpulkan adalah bahan yang sesuai dan relevan dengan mata pelajaran Fikih materi Haji dan Umrah untuk siswa MTs. untuk membantu memberikan penjelasan terhadap materi yang dibahas; misalnya video manasik haji, gambar ihram, gambar melakukan tawaf, gambar melempar jumrah dan lain-lain.

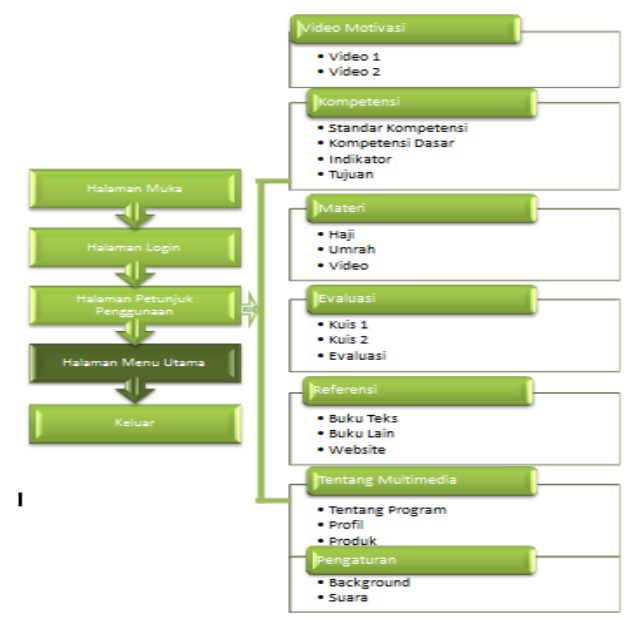

Gambar 4. Flowchat Media Pembelajaran Haji dan Umrah untuk siswa MTs.
Langkah kedua adalah membuat story-board yaitu untuk menuangkan diagram alur (flowchart) dan bahan-bahan pendukung ke dalam program CD pembelajaran. Dengan storyboard akan dapat menetapkan materi Haji dan Umrah, jenis visual yang menjadi isi media yang ditampilkan, dan bahan pendukung lain. Seluruh materi Haji dan Umrah, jenis visual, dan bahan pendukungnya diatur dan diprogram sesuai flowchart sehingga dapat dilihat bahwa: (1) semua visualisasi telah cocok dengan teks, (2) pengantar dan pendahuluan menarik perhatian, (3) informasi penting telah dicakup, dan (4) alur dan organisasi program mudah diikuti dan dimengerti.

Langkah ketiga memasukkan bahan-bahan tersebut ke dalam program. Program yang digunakan dalam pengembangan CD pembelajaran materi Haji dan Umrah untuk siswa MTS. adalah program Macromedia Flash 8, Adobe Photoshop CS5, Corel Draw11, dan Xilisoft Video Converter 3.

Langkah keempat dalam pengembangan produk ini adalah memproduksi produk, yaitu mempublish program media pembelajaran PAI materi Haji dan Umrah berbatuan komputer atau CAI (Computer Assisted Instruction) dalam bentuk compact disc (CD) pembelajaran yang siap untuk dievaluasi.

\section{Evaluasi}

Kelayakan media pembelajaran berbantuan komputer atau CAI (Computer Assisted Instruction) melalui produk multimedia dalam bentuk CD pembelajaran niscaya mendukung implementasi proses pembelajaran. Kelayakan dan keniscayaan tersebut harus telah dievaluasi melalui validasi dan diuji coba oleh ahli media, ahli materi, uji empirik terbatas, maupun uji coba lapangan. Pengujian dan validasi CD pembelajaran materi Haji dan Umrah untuk siswa MTs. ini terdiri dari satu orang ahli media, 4 orang guru mata pelajaran Fikih di MTs Negeri Yogyakarta 1 sebagai ahli materi, dan uji lapangan kepada siswa MTs Negeri Yogyakarta 1. Data dan saran 
yang ada pada instrumen digunakan sebagai bahan pertimbangan untuk perbaikan dan merevisi media pembelajaran.

Validasi oleh ahli media pembelajaran dilakukan dengan mekanisme memberikan hasil pengembangan media pembelajaran yang sudah jadi dalam bentuk CD kemudian ahli media memberikan penilaian terhadap media tersebut dalam bentuk angket isian. Validasi oleh ahli media berisi aspek tampilan dan aspek pemrograman. Hasil penilaian aspek tampilan yang diperoleh dari ahli media setelah dikonversi dalam skala 4 diperoleh nilai skor rerata 3,24, skor ini masuk dalam kriteria baik. Lebih jelas dapat dilihat pada Table 2.

Tabel 2. Validasi Ahli Media terhadap Aspek Tampilan

\begin{tabular}{llccc}
\hline No & Komponen & $\begin{array}{c}\text { Juml ah } \\
\text { Indikator }\end{array}$ & Skor & Persentase \\
\hline 1. & Komp. Warna & 2 & 3,5 & 87,5 \\
2. & KualitasAudio & 3 & 3,3 & 83,3 \\
3. & Kualitas Video & 5 & 3,4 & 85 \\
4. & Kualitas Tombol & 2 & 3 & 75 \\
5. & Kejelasan Teks & 3 & 3 & 75 \\
6. & Kualitas Gambar & 3 & 3 & 75 \\
7. & Desain Slide & 2 & 3,5 & 87,5 \\
\hline \multicolumn{7}{l}{ Total Skor } & 20 & 3,24 & 81 \\
\hline
\end{tabular}

Sedang hasil penilaian aspek pemrograman yang diperoleh dari ahli media setelah dikonversi dalam skala 4 diperoleh nilai skor rerata 3,17 , skor ini masuk dalam kriteria baik. Lebih jelas dapat dilihat pada tabel berikut.

Tabel 3. Validasi Ahli Media Terhadap Aspek Pemrograman

\begin{tabular}{ccccc}
\hline No. & \multicolumn{1}{c}{ Komponen } & $\begin{array}{c}\text { Jumlah } \\
\text { Indikator }\end{array}$ & Skor & Persentase \\
\hline 1. & Tingkat dan & 2 & 4 & 100 \\
& kemudahan interaksi & & & \\
2. & Penggunaan navigasi & 2 & 3 & 75 \\
3. $\begin{array}{l}\text { Kualitas animasi } \\
\text { 4. Efisiensi teks dan }\end{array}$ & 2 & 3 & 75 \\
& 2 & 3 & 75 \\
Slide & & & \\
5. Petunjuk Penggunaan & 1 & 3 & 75 \\
6. Umpan balik & 1 & 3 & 75 \\
\hline Total Skor & 10 & 3,17 & 79,17 \\
\hline
\end{tabular}

Berdasarkan penilaian dan validasi yang diberikan oleh ahli media bahwa CD pembelajaran materi Haji dan Umrah yang dikembangkan untuk siswa MTs. dapat dikategorikan "baik" sehingga layak untuk digunakan sebagai pendukung pembelajaran. Ahli media memberi saran dan masukan agar CD pembelajaran ini menjadi "sangat baik" maka icon-icon pada aspek materi sebaiknya dilengkapi teks dan aspek materi perlu diberi nomor sesuai dengan nomor menu.

Validasi oleh ahli materi dilakukan dengan mekanisme yang sama seperti pada ahli media meliputi aspek isi (materi) dan aspek pembelajaran. Ahli materi diambil dari 4 orang guru PAI MTs. Negeri Yogyakarta 1 yang sudah lama mengajar mata pelajaran Fikih. Mereka diberi hasil pengembangan media pembelajaran yang sudah jadi dalam bentuk $C D$ untuk memberikan penilaian terhadap media tersebut dalam bentuk angket isian. Hasil penilaian aspek materi yang diperoleh dari ahli materi setelah dikonversi dalam skala 4 diperoleh nilai skor rerata 3,42, skor ini masuk dalam kriteria baik. Lebih jelas dapat dilihat pada tabel berikut.

Tabel 4. Validasi Ahli Materi terhadap Aspek Isi (Materi)

\begin{tabular}{llccc}
\hline $\begin{array}{l}\text { No } \\
.\end{array}$ & Komponen & $\begin{array}{c}\text { Jumlah } \\
\text { Indikator }\end{array}$ & Skor & Persentase \\
\hline 1. & Kualitas materi & 6 & 3,25 & 81,25 \\
2. & Kualitas visual & 3 & 3,91 & 97,91 \\
3. & Kualitas & 3 & 3.12 & 79,16 \\
& evaluasi & & & \\
\hline Total Skor & 12 & 3,42 & 85,66 \\
\hline
\end{tabular}

Sedang hasil penilaian aspek pembelajaran yang diperoleh dari ahli materi setelah dikonversi dalam skala 4 diperoleh nilai skor rerata 3,52; skor ini masuk dalam kriteria baik menuju sangat baik. Lebih jelas dapat dilihat pada tabel berikut.

Tabel 5. Validasi Ahli Materi terhadapAspek Pembelajaran

\begin{tabular}{llccc}
\hline No. & \multicolumn{1}{c}{ Komponen } & $\begin{array}{c}\text { Jumlah } \\
\text { Indikator }\end{array}$ & Skor & Persentase \\
\hline 1. & Tujuan & 2 & 3,25 & 81,25 \\
2. & Motivasi & 1 & 4 & 100 \\
3. & Permilihan materi & 4 & 3,88 & 96,88 \\
4. & Sajian soal \& latihan & 4 & 3,25 & 81,25 \\
5. Kebahasaan & 1 & 3,25 & 81,25 \\
6. & Tanggapan terhadap & 2 & 3,25 & 81,25 \\
& respon siswa & & & \\
7. & Petunjuk belajar & 3 & 3,75 & 93,75 \\
\hline Total Sor & 17 & 3,52 & 88 \\
\hline
\end{tabular}


Berdasarkan penilaian dan validasi yang diberikan oleh ahli materi dari guru mata pelajaran Fikih MTs. Negeri Yogyakarta 1, bahwa CD pembelajaran Haji dan Umrah yang dikembangkan untuk siswa MTs. dapat dikategorikan "sangat baik" sehingga layak untuk digunakan sebagai pendukung pembelajaran dan belajar mandiri. Ahli materi memberi saran dan masukan agar CD pembelajaran ini menjadi keharusan media pembelajaran bagi guru-guru di MTs., terutama bagi guru yang mengajar Pendidikan Agama Islam (PAI).

\section{Uji Coba CD Pembelajaran kepada Siswa}

Uji coba CD pembelajaran kepada siswa MTs. Negeri Yogyakarta 1 dilakukan tiga tahap, yaitu tahap uji coba satu satu (one on one), tahap uji coba sampel kecil, dan tahap uji coba sampel besar. Pada uji coba CD pembelajaran ini siswa diberi angket untuk mengisi sesuai dengan pilihan jawaban siswa yang meliputi aspek tampilan berisi 14 item pernyataan, aspek isi atau materi berisi 7 item pertanyaan, dan aspek pembelajaran berisi 14 item pertanyaan yang mengacu kepada aspek kelayakan isi/materi dan aspek media (sajian/tampilan). Pengujian dilakukan untuk mengetahui tanggapan siswa terhadap kelayakan dan kualitas CD Pembelajaran yang dikembangkan. Hasil isian angket terhadap semua aspek yang dinilai disajikan pada Tabel 6 .

Tabel 6. Uji Coba kepada Siswa "one on one" terhadap Aspek Tampilan

\begin{tabular}{|c|c|c|c|}
\hline No. & Komponen & Skor & Persentase \\
\hline 1. & Warna gambar & 3,67 & 91,67 \\
\hline 2. & $\begin{array}{l}\text { Kejelasan suara video dan } \\
\text { musik }\end{array}$ & 3,67 & 91,67 \\
\hline 3. & Kejelasan gambar video & 4 & 100 \\
\hline 4. & $\begin{array}{l}\text { Navigasi: kemudahan } \\
\text { pengunaan dan memilih } \\
\text { menu }\end{array}$ & 3,88 & 97,22 \\
\hline 5. & Keterbacaan teks & 3,67 & 91,67 \\
\hline 6. & $\begin{array}{l}\text { Kejelasan bentuk gambar, } \\
\text { warna dan ukuran gambar }\end{array}$ & 3,67 & 91,67 \\
\hline 7. & Tampilan slide animasi & 4 & 100 \\
\hline 8. & $\begin{array}{l}\text { Kejelasan petunjuk } \\
\text { penggunaan }\end{array}$ & 3,67 & 91,67 \\
\hline \multicolumn{2}{|c|}{ Total Skor } & 3,78 & 94,46 \\
\hline
\end{tabular}

Tabel menjelaskan hasil uji coba one on one kepada siswa MTs. Negeri Yogyakarta 1 terhadap aspek tampilan CD pembelajaran Haji dan Umrah yang menunjukan pada skor rata-rata 3,78 atau $94,46 \%$. Hasil rata-rata skor dan persentase ini berada pada skala "sangat baik" yang meliputi komponen warna gambar, kejelasan suara video dan ketepatan musik, kejelasan gambar video, navigasi/tombol, keterbacaan teks, kejelasan bentuk gambarwarna dan ukuran gambar, tampilan slide animasi, dan kejelasan petunjuk penggunaan. Berdasarkan uji coba tersebut diperoleh data kuantitatif yang menunjukkan bahwa CD media pembelajaran dalam aspek tampilan layak dan dapat dipakai dengan kriteria sangat baik (skor 3,78).

Tabel 7. Uji Coba kepada Siswa "one on one" terhadap Aspek Materi

\begin{tabular}{clcc}
\hline No. & \multicolumn{1}{c}{ Komponen } & Skor & Persentase \\
\hline 1. & Kejelasan materi & 3,67 & 91,67 \\
2. $\begin{array}{l}\text { Kejelasan dan kelugasan } \\
\text { bahasa }\end{array}$ & 3,33 & 83,33 \\
$\begin{array}{l}\text { 3. Kualitas visual: ketepatan } \\
\text { gambar dan video untuk }\end{array}$ & 3,83 & 95,83 \\
$\quad \begin{array}{l}\text { menjekaskan materi } \\
\text { 4. Kualitas rumusan soal }\end{array}$ & 3,83 & 95,83 \\
\hline Total Skor & 3,66 & 91,625 \\
\hline
\end{tabular}

Tabel 7 menjelaskan hasil uji coba one on one kepada siswa MTs. Negeri Yogyakarta 1 terhadap aspek isi/materi CD pembelajaran Haji dan Umrah yang menunjukan pada skor rata-rata 3,66 atau $91,625 \%$. Hasil rata-rata skor dan persentase ini berada pada skala "sangat baik" yang meliputi komponen kejelasan materi, kejelasan dan kelugasan bahasa, kualitas visual yaitu ketepatan gambar dan video untuk menjelaskan materi, serta kualitas rumusan soal. Berdasarkan uji coba tersebut diperoleh data kuantitatif yang menunjukkan bahwa CD media pembelajaran dalam aspek materi layak dan dapat dipakai dengan kriteria sangat baik (skor $3,66)$.

Pada uji coba one on one kepada siswa terhadap aspek pembelajaran menunjukan pada skor rata-rata 3,47 atau $86,78 \%$. Hasil skor rata-rata tersebut dapat dilihat pada Tabel 8 . 
Tabel 8. Uji Coba kepada Siswa "one on one" terhadap Aspek Pembelajaran

\begin{tabular}{clcc}
\hline No. & \multicolumn{1}{c}{ Komponen } & Skor & Persetase \\
\hline 1. & $\begin{array}{l}\text { Fungsi media } \\
\text { membantu belajar }\end{array}$ & 3,33 & 83,33 \\
2. $\begin{array}{l}\text { Kemudahan } \\
\text { mempelajari materi }\end{array}$ & 3,33 & 83,33 \\
3. $\begin{array}{l}\text { Materi menjadi } \\
\text { menarik }\end{array}$ & 3,33 & 83,33 \\
4. & $\begin{array}{l}\text { Kesesuaian materi } \\
\text { dengan soal }\end{array}$ & 3,66 & 91,66 \\
5. $\begin{array}{l}\text { Kemudahan } \\
\text { memahami kalimat } \\
\text { dalam uraian materi } \\
\text { (Kebahasaan) }\end{array}$ & 3,66 & 91,66 \\
6. $\begin{array}{l}\text { Umpan balik untuk } \\
\text { jawaban siswa }\end{array}$ & 3,33 & 83,33 \\
7. $\begin{array}{l}\text { Memberikan } \\
\text { petunjuk dalam } \\
\text { belajar }\end{array}$ & 3,55 & 88,88 \\
Memotifasi siswa & 3,58 & 89,58 \\
\hline Total Skor & 3,47 & 86,78 \\
\hline
\end{tabular}

Tabel 8 menjelaskan hasil uji coba one on one kepada siswa MTs. Negeri Yogyakarta 1 terhadap aspek pembelajaran CD pembelajaran Haji dan Umrah yang menunjukan pada skor rata-rata 3,47 atau $86,78 \%$. Hasil rata-rata skor dan persentase ini berada pada skala "baik" yang meliputi komponen fungsi media, kemudahan mempelajari materi, materi menjadi menarik, kesesuaian materi dengan soal evaluasi, kemudahan memahami uraian materi, memberi umpan balik kepada siswa, memberikan petunjuk dalam belajar, dan memotivasi siswa. Berdasarkan uji coba tersebut diperoleh data kuantitatif yang menunjukkan bahwa CD media pembelajaran dalam aspek pembelajaran layak dan dapat dipakai dengan kriteria baik (skor 3,47).

Ketiga tabel tersebut di atas yaitu dari aspek tampilan, aspek materi, dan aspek pembelajaran dapat dirangkumkan dalam tabel 9.

Tabel 9. Hasil Uji Coba "One on One" tentang Kelayakan Produk

\begin{tabular}{cccc}
\hline No. & \multicolumn{1}{c}{ Aspek } & Skor & Persentase \\
\hline 1. & Aspek Tampilan & 3,78 & 94,46 \\
2. & Aspek Materi & 3,66 & 91,625 \\
3. & Aspek Pembelajaran & 3,47 & 86,78 \\
\hline Total Skor & 3,63 & 90,91 \\
\hline
\end{tabular}

Tabel 9 menjelaskan bahwa produk CD pembelajaran materi Haji dan umrah untuk siswa MTs. yang diujicobakan hasilnya sangat baik dan layak (rata-rata skor 3,63 atau 90,91\%).

Pada uji coba sampel kecil kepada 10 orang siswa MTs. hasil isian angket terhadap semua aspek (aspek tampilan, materi, dan pembelajaran) yang dinilai disajikan pada tabel di bawah.

\begin{tabular}{|c|c|c|c|}
\hline No. & Komponen & Skor & Persentase \\
\hline 1. & Warna gambar & 3,3 & 82,5 \\
\hline 2. & $\begin{array}{l}\text { Audio: kejelasan suara } \\
\text { video dan ketepan } \\
\text { music }\end{array}$ & 3,0 & 75 \\
\hline 3. & $\begin{array}{l}\text { Kejelasan gambar } \\
\text { video }\end{array}$ & 3,4 & 85 \\
\hline 4. & $\begin{array}{l}\text { Navigasi: kemudahan } \\
\text { pengunaan dan } \\
\text { memilih menu }\end{array}$ & 3,2 & 80 \\
\hline 5. & Keterbacaan teks & 3,4 & 85 \\
\hline 6. & $\begin{array}{l}\text { Kejelasan bentuk } \\
\text { gambar, warna dan } \\
\text { ukuran gambar }\end{array}$ & 3,4 & 85 \\
\hline 7. & Tampilan slide animasi & 3,0 & 75 \\
\hline 8. & $\begin{array}{l}\text { Kejelasan petunjuk } \\
\text { penggunaan }\end{array}$ & 3,4 & 85 \\
\hline \multicolumn{2}{|c|}{ Total Skor } & 3,26 & 81,56 \\
\hline
\end{tabular}

Tabel 10 menjelaskan hasil uji coba sampel kecil kepada siswa MTs. Negeri Yogyakarta 1 terhadap aspek tampilan CD pembelajaran Haji dan Umrah yang menunjukan pada skor rata-rata 3,26 atau $81,56 \%$. Hasil rata-rata skor dan persentase ini berada pada skala "baik" yang meliputi komponen warna gambar, kejelasan suara video dan ketepatan musik, kejelasan gambar video, navigasi/tombol, keterbacaan teks, kejelasan bentuk gambar-warna dan ukuran gambar, tampilan slide animasi, dan kejelasan petunjuk penggunaan. Adapun uji coba kepada siswa "sampel kecil" terhadap aspek materi disajikan pada Tabel 11.

Tabel 11 menjelaskan hasil uji coba sampel kecil kepada siswa MTs. Negeri Yogyakarta 1 terhadap aspek isi/materi CD pembelajaran Haji dan Umrah yang menunjukan pada skor rata-rata 3,25 atau 
$81,25 \%$. Hasil rata-rata skor dan persentase ini berada pada skala "baik" yang meliputi komponen kejelasan materi, kejelasan dan kelugasan bahasa, kualitas visual yaitu ketepatan gambar dan video untuk menjelaskan materi, serta kualitas rumusan soal. Sedang uji coba kepada siswa "sampel kecil" terhadap aspek pembelajaran disajikan pada Tabel 12.

Tabel 11. Uji Coba kepada Siswa "sampel kecil" terhadap Aspek Materi

\begin{tabular}{rlcc}
\hline No. & \multicolumn{1}{c}{ Komponen } & Skor & Persentase \\
\hline 1. & Kejelasan materi & 3,40 & 85 \\
2. & $\begin{array}{l}\text { Kejelasan dan kelugasan } \\
\text { bahasa }\end{array}$ & 3,20 & 80 \\
3. & $\begin{array}{l}\text { Kualitas visual: ketepatan } \\
\text { gambar dan video untuk }\end{array}$ & 3,20 & 80 \\
$\quad \begin{array}{l}\text { menjekaskan materi } \\
\text { 4. }\end{array}$ & 3,20 & 80 \\
\hline Total Skor & 3,25 & 81,25 \\
\hline
\end{tabular}

Tabel 12. Uji Coba kepada Siswa "sampel kecil" Aspek Pembelajaran

\begin{tabular}{|c|c|c|c|}
\hline No. & Komponen & Skor & Persentase \\
\hline 1. & $\begin{array}{l}\text { Fungsi media membantu } \\
\text { belajar }\end{array}$ & 3,90 & 97,5 \\
\hline 2. & $\begin{array}{l}\text { Kemudahan mempelajari } \\
\text { materi }\end{array}$ & 3,30 & 82,5 \\
\hline 3. & Materi menjadi menarik & 3,60 & 90 \\
\hline & $\begin{array}{l}\text { Kesesuaian materi dengan } \\
\text { soal }\end{array}$ & 3,60 & 90 \\
\hline & $\begin{array}{l}\text { Kemudahan memahami } \\
\text { kalimat dalam uraian } \\
\text { materi }\end{array}$ & 3,30 & 82,5 \\
\hline & $\begin{array}{l}\text { Umpan balik untuk } \\
\text { jawaban siswa }\end{array}$ & 3,20 & 80 \\
\hline & $\begin{array}{l}\text { Memberikan petunjuk } \\
\text { dalam belajar }\end{array}$ & 3,30 & 82,5 \\
\hline & Memotifasi siswa & 3,58 & 89,58 \\
\hline Tota & al Skor & 3,47 & 86,78 \\
\hline
\end{tabular}

Tabel 12 menjelaskan hasil uji coba sampel kecil kepada siswa MTs. Negeri Yogyakarta 1 terhadap aspek pembelajaran CD pembelajaran Haji dan Umrah yang menunjukan pada skor rata-rata 3,47 atau $86,78 \%$. Hasil rata-rata skor ini berada pada skala "baik" yang meliputi komponen fungsi media membatu belajar, kemudahan mempelajari materi, materi menjadi menarik, kesesuaian materi dengan soal evaluasi, kemudahan memahami uraian materi, memberi umpan balik kepada siswa, memberikan petunjuk dalam belajar, dan memotivasi siswa.
Berdasarkan jawaban uji coba "sampel kecil" tentang produk CD Pembelajaran dilihat dari aspek tampilan, aspek materi, dan aspek pembelajaran dapat dirangkumkan dalam Tabel 13.

Tabel 13. Hasil Uji Coba "Sampel Kecil" tentang Kelayakan Produk

\begin{tabular}{clcc}
\hline No. & Aspek & Skor & Persentase \\
\hline 1. & Aspek Tampilan & 3,26 & 81,50 \\
2. & Aspek Materi & 3,25 & 81,25 \\
3. & Aspek Pembelajaran & 3,47 & 86,75 \\
\hline Total Skor & 3,33 & 83,25 \\
\hline
\end{tabular}

Tabel 13 menjelaskan bahwa produk CD Pembelajaran yang diujicobakan hasilnya baik dan layak untuk dijadikan media pembelajaran, yaitu CD multimedia pembelajaran materi Haji dan Umrah untuk siswa MTs.

Berdasarkan validasi dari ahli media dan ahli materi tersebut di atas, serta uji coba one on one dan sampel kecil terhadap siswa MTs. Negeri Yogyakarta 1 bahwa produk CD pembelajaran Haji dan Umrah yang dikembangkan untuk siswa MTs. memenuhi syarat kelayakan dan dinilai pada kriteria "baik". Agar lebih memenuhi syarat kelayakan untuk uji coba sampel besar terhadap siswa MTs. Negeri Yogyakarta 1, maka produk CD pembelajaran perlu dilakukan revisi meliputi: 1) Video Motivasi: a) ditampilkan video motivasi manasik haji (bukan slide foto) yang bergerak sehingga lebih interaktif dan disesuaikan dengan usia siswa MTs. Kelas IX, b) video motivasi perlu diperbaiki agar dapat berfungsi dengan baik; 2) Menu Utama: susunan menu utama diubah agar lebih mudah dalam pemakaian, menjadi: Video Motivasi - Kompetensi - Materi Evaluasi - Referensi - Tentang Media Pengaturan; 3) Materi Utama: a) materi sebaiknya dikembangkan secara detil karena digunakan untuk belajar mandiri, $b$ ) teks Arab dibuat lebih readable (terbaca) dan ukuran yang cukup besar; 4) Materi Haji: a) niat dan syarat-syarat rukun Haji dilengkapi, b) materi rukun Haji ditambah satu poin terakhir yaitu tertib, c) sub materi syarat sah Haji disesuaikan isi materinya 
sesuai sumber belajar; 5) Video Haji: a) video Haji disempurnakan agar seluruh rukunnya terlaksana, b) suara materi dan lirik/ lagu pengiringnya diseimbangkan; 6) Evaluasi: a) soal evaluasi ditambah imagenya, b) setiap akhir sub materi ditambah kuis; 7) Tampilan dan penulisan: a) menggunakan font-font yang senserif (seperti arial, calibri, dan lain-lain), b) ukuran font disesuaikan, c) teks dibuat justify (rata kanan dan kiri), d) dilengkapi tombol navigasi (next -previous), e) animasi perlu ditingkatkan.

Uji Coba Sampel Besar terhadap Siswa MTs

Uji coba CD Pembelajaran untuk sampel besar diberikan kepada 36 siswa MTs. Negeri Yogyakarta 1 melalui angket yang telah dipersiapkan. Angket yang diberikan untuk uji coba sampel besar sebagai uji coba bagian akhir sama dengan angket untuk uji coba one on one dan uji coba sampel kecil. Pengujian dilakukan untuk mengetahui tanggapan siswa terhadap kelayakan dan kualitas CD Pembelajaran yang dikembangkan. Hasil isian angket terhadap semua aspek yang dinilai disajikan pada Tabel 14.

Tabel 14. Uji Coba kepada Siswa "sampel besar" terhadap Aspek Tampilan

\begin{tabular}{|c|c|c|c|}
\hline No. & Komponen & Skor & Persentase \\
\hline 1. & Tampilan gambar & 3,33 & 83,25 \\
\hline 2. & $\begin{array}{l}\text { Tampilan Audio: } \\
\text { kejelasan suara video dan } \\
\text { ketepan music }\end{array}$ & 3,0 & 75 \\
\hline 3. & Tampilan gambar video & 3,14 & 78,50 \\
\hline 4. & $\begin{array}{l}\text { Navigasi/tombol: } \\
\text { kemudahan pengunaan } \\
\text { dan memilih menu }\end{array}$ & 3,22 & 80,50 \\
\hline 5. & $\begin{array}{l}\text { Tampilan dan } \\
\text { Keterbacaan teks }\end{array}$ & 3,38 & 84,50 \\
\hline 6. & $\begin{array}{l}\text { Kejelasan bentuk gambar, } \\
\text { warna dan ukuran } \\
\text { gambar }\end{array}$ & 3,27 & 81,75 \\
\hline 7. & Tampilan slide animasi & 3,0 & 75 \\
\hline & $\begin{array}{l}\text { Kejelasan petunjuk } \\
\text { penggunaan }\end{array}$ & 3,44 & 86 \\
\hline Tota & 1Skor & 3,22 & 80,50 \\
\hline
\end{tabular}

Tabel 14 menjelaskan hasil uji coba sampel besar kepada 36 siswa MTs. Negeri Yogyakarta 1 terhadap aspek tampilan CD pembelajaran materi Haji dan Umrah yang menunjukan pada skor rata-rata 3,22 atau $80,50 \%$. Hasil rata-rata skor dan persentase tersebut menjelaskan tampilan gambar, audio, video, dan navigasi menurut siswa MTs. berada pada skala "baik". Tampilan CD Pembelajaran yang dikembangkan meliputi komponen warna gambar, kejelasan suara video dan ketepatan musik, kejelasan gambar video, navigasi/tombol, keterbacaan teks, kejelasan bentuk gambar-warna dan ukuran gambar, tampilan slide animasi, dan kejelasan petunjuk penggunaan. Adapun uji coba aspek materi disajikan pada table berikut.

Tabel 15. Uji Coba kepada Siswa "sampel besar" terhadap Aspek Materi

\begin{tabular}{clcc}
\hline No. & \multicolumn{1}{c}{ Komponen } & Skor & Persentase \\
\hline 1. & Kejelasan materi & 3,22 & 80,50 \\
2. & Kejelasan dan kelugasan & 3,27 & 81,75 \\
& bahasa & \\
3. & Kualitas visual: ketepatan & 3,27 & 81,75 \\
& $\begin{array}{l}\text { gambar dan video materi } \\
\text { 4. Kualitas rumusan soal }\end{array}$ & 3,22 & 80,50 \\
\hline Total Skor & 3,24 & 81 \\
\hline
\end{tabular}

Tabel 15 menjelaskan pernyataan siswa terhadap aspek isi/materi pengembangan media pembelajaran Haji dan Umrah menunjukkan pada skor rata-rata 3,24 atau $81 \%$. Hasil rata-rata skor dan persentase ini berada pada kriteria "baik" yang meliputi komponen kejelasan materi, kejelasan dan kelugasan bahasa, kualitas visual yaitu ketepatan gambar dan video untuk menjelaskan materi, serta kualitas rumusan soal. Sedang ujicoba aspek pembelajaran disajikan pada Tabel 16 .

Tabel 16 menjelaskan hasil uji coba sampel besar 36 siswa MTs. Negeri Yogyakarta I terhadap pengembangan media pembelajaran materi Haji dan Umrah menunjukkan skor rata-rata 3,37 atau $84,25 \%$. Hasil rata-rata skor dan persentase ini berada pada skala "baik". Hasil ujicoba "sampel besar" tentang produk CD pembelajaran di atas dapat dirangkum dalam Tabel 17. 
Tabel 16. Uji Coba kepada Siswa "sampel besar" terhadap Aspek Pembelajaran

\begin{tabular}{|c|c|c|c|}
\hline No. & Komponen & Skor & Persentase \\
\hline 1. & $\begin{array}{l}\text { Fungsi media membantu } \\
\text { belajar }\end{array}$ & 3,44 & 86 \\
\hline 2. & $\begin{array}{l}\text { Kemudahan } \\
\text { mempelajari materi }\end{array}$ & 3,38 & 84,5 \\
\hline 3. & Materi menjadi menarik & 3,44 & 86 \\
\hline 4. & $\begin{array}{l}\text { Kesesuaian materi } \\
\text { dengan soal }\end{array}$ & 3,14 & 78,5 \\
\hline 5. & $\begin{array}{l}\text { Kemudahan memahami } \\
\text { kalimat dalam uraian } \\
\text { materi }\end{array}$ & 3,38 & 84,5 \\
\hline 6. & $\begin{array}{l}\text { Umpan balik untuk } \\
\text { jawaban siswa }\end{array}$ & 3,33 & 83,25 \\
\hline 7. & $\begin{array}{l}\text { Memberikan petunjuk } \\
\text { dalam belajar }\end{array}$ & 3,38 & 84,5 \\
\hline 8. & Memotivasi siswa & 3,44 & 86 \\
\hline Total & Skor & 3,37 & 84,25 \\
\hline
\end{tabular}

Tabel 17. Uji Coba "Sampel Besar" tentang Kelayakan Produk CD Pembelajaran

\begin{tabular}{clcc}
\hline No. & Aspek & Skor & Persentase \\
\hline 1. & Aspek Tampilan & 3,22 & 80,50 \\
2. Aspek Materi & 3,24 & 81,00 \\
3. & Aspek Pembelajaran & 3,37 & 84,25 \\
\hline \multicolumn{2}{l}{ Total Skor } & 3,28 & 82,00 \\
\hline
\end{tabular}

Tabel 17 menjelaskan bahwa pengembangan media pembelajaran yang diujicobakan pada sampel besar kepada 36 siswa MTs. Negeri Yogyakarta I hasilnya baik dan layak. Hasil uji coba ini mempertegas bahwa penelitian dan pengembangan tentang pengembangan media pembelajaran materi Haji dan Umrah dapat dijadikan media pembelajaran PAI untuk guru dan siswa di MTs. kelas IX.

Berdasarkan validasi dari ahli media dan ahli materi serta ujicoba terhadap 36 siswa MTs. Negeri Yogyakarta 1 sebagai kajian produk akhir, hasilnya dituangkan pada Tabel 18.

Tabel 18. Hasil Validasi dan Ujicoba

Pengembangan Media Pembelajaran

\begin{tabular}{llcc}
\hline No. & Validasi/Uji Coba & $\begin{array}{c}\text { Skor } \\
\text { Rerata }\end{array}$ & Persentase \\
\hline 1. Validasi Ahli Media & 3,20 & 80 \\
2. Validasi Ahli Materi & 3,47 & 86,75 \\
3. Uji Coba Siswa One on One & 3,63 & 90,75 \\
4. Uji Coba Siswa Sampel & 3,33 & 83,25 \\
& & \\
Kecil & 3,28 & 82 \\
5. Uji Coba Siswa Sampel & & \\
$\quad$ Besar & 3,38 & 84,5 \\
\hline
\end{tabular}

Tabel 18 menjelaskan bahwa media pembelajaran materi Haji dan Umrah yang dikembangkan untuk siswa MTs. Memenuhi syarat kelayakan dan pada hasil skor 3,38 atau kriteria "baik". Artinya pengembangan media pembelajaran materi Haji dan Umrah untuk siswa MTs. "layak dan dapat" digunakan sebagai media pembelajaran berbasis komputer (Computer Assisted Intruction).

\section{Simpulan dan Saran}

Simpulan

Pengembangan program CAI dalam pembelajaran PAI menghasilkan CD pembelajaran materi Haji dan Umrah untuk siswa MTs. kelas IX semester gasal. Produk software dikembangkan dengan menggunakan program Macromedia Flash 8, dan didukung software-software lainnya, seperti: CorelDRAW 11, Adobe Photoshop versi CS5, Xilisoft video converter3, dll.

Berdasarkan validasi dan ujicoba di lapangan bahwa pengembangan media pembelajaran PAI dinyatakan layak berdasarkan validasi ahli media dan validasi ahli materi, serta hasil ujicoba kepada siswa MTs. Negeri Yogyakarta 1 dengan skor 3,38 atau pada kriteria "baik". Artinya pengembangan media pembelajaran berbasis CAI materi Haji dan Umrah untuk siswa MTs. "layak dan dapat" digunakan sebagai media pembelajaran.

Media pembelajaran ini memberi sumbangan dalam proses pembelajaran di kelas yaitu siswa merasa mudah mempelajari materi; materi pembelajaran menjadi menarik; memberi umpan balik kepada siswa dan guru, dan memotivasi siswa untuk selalu belajar dengan skor rata-rata $3,37(84,25 \%)$.

\section{Saran}

Penelitian pengembangan atau $\mathrm{R} \&$ $\mathrm{D}$ (Research and Development) yang menghasilkan suatu program media pembelajaran memerlukan penelitian lebih lanjut sehingga diseminasi pemanfaatan dan 
perbaikan produk media menjadi lebih ideal. Di samping itu perlu diadakan program peningkatan kemampuan guru MTs. dalam pemrograman komputer, baik dalam bentuk workshop ataupun diklat sehingga para guru MTs. dapat mengembangkan dan memanfaatkannya.

\section{Daftar Pustaka}

Al-Jumlati, Ali. (1973). Dirrasah muqaranah fi al-tarbiyah al-Islamiyah.Cairo: Maktabah Angelo Al Mishriyyah.

Anik Gufron. (2007). Pendekatan penelitian dan pengembangan. Yogyakarta: LPMP.

Azyumardi Azra. (1999). Menuju masyarakat madani: gugatan, fakta, dan tantangan. Jakarta: Rosda Karya.

Borg, W. R and Meredith Damien Gall. (1983). Educational research. An Introduction. Fourth Edition. New York: logman.

Conny R. Semiawan. (1995). Pendidikan agama dalam perspektif agama-agama. Jakarta: Diknas-Ditjen. Dikti.

Departemen Agama RI. (2004). Membiasakan tradisi agama: Arah baru pendidikan agama Islam (PAI) pada sekolah umum. Jakarta: Ditjen Kelembagaan Agama Islam.

Depdiknas. (2003). Undang-Undang RI Nomor 20,Tahun 2003, tentang Sistem Pendidikan Nasional.

Dick, Walter; Carey, Lou and Carey, James O. (2005). The systematic design of instructtion. Boston: Allyn and Bacon, Permissions Department.

Hannafin, Michael J. \& Kyle L. Peck (1988). The Design, development and evaluation of instructional software. New York: Mcmillan Publishing Company.

Kuntowijoyo. (2005). Islam sebagai ilmu: Epistemologi, metodologi, dan etika. Jakarta: Terayu Press.

Orey, Michael, et al. (2006). Educational media and technology yearbook. London: Published in cooperation with the AECT.

Sadiman, Arief S., dkk. (2006). Media pendidikan, pengertian, pengembangan dan pemanfaatannya. Jakarta: PT. Raja Grafindo Persada.

Sutopo, Aristo Hadi. (2003). Multimedia interaktif dengan flash. Yogyakarta: Grana Ilmu. 